\title{
An Illiberal Descent: Natural and National History in the Work of Charles Kingsley
}

\author{
JONATHAN CONLIN \\ University of Southampton
}

\begin{abstract}
The Victorian novelist, historian and cleric Charles Kingsley (1819-75) was a polymath who took a close interest in natural history. A friend and correspondent of T. H. Huxley and many other leading British and American biologists, Kingsley applied concepts familiar from evolutionary biology in his historical novels and lectures. Rather than being a straightforward case of dressing literary works in language made fashionable and exciting by the boom of post-Darwinian speculation on evolution, Kingsley sought to construct a 'Natural Theology' for the Victorian age, one in which natural and national history merged completely. This encouraged him to present the history of Britain as the history of a divinely favoured Teutonic race, one with a mission to subdue the world. Less favoured races were doomed to assimilation into this race or to complete annihilation. Such racialist thinking was, this essay suggests, not unusual in Victorian historical writing. Accounts of Victorian historiography structured around the professionalization of a new discipline of history may have caused us to overlook 'amateurs' such as Kingsley, despite the fact that their historical works remained popular well into the twentieth century.
\end{abstract}

\footnotetext{
I
} n July 1862 the Rev. Charles Kingsley wrote to the biologist T. H. Huxley of his excitement in the wake of the publication of Charles Darwin's Origin of Species. 'I am as one overwhelmed and astounded by the grand views Mr Darwin's theories open to me at every turn', he wrote, and added: 'I believe that he has inaugurated a new era to me, as well as to your strictly scientific men; for all natural theology must be rewritten during the next century, by the light of his hints - for they are no more than hints - but hints wh[ich] will be, when modified by fresh knowledge, the parents of a whole new science. ${ }^{1}$ Best known today as the author of The Water Babies (1862), as a Christian Socialist and father of that variety of Anglican, public-school activism known as 'Muscular

\footnotetext{
Research for this essay was funded by a Leverhulme Early Career Fellowship, and the author would like to thank the Foundation for their generous support, as well as the Friends of Princeton University Library for their award of a Fellowship, which enabled him to study Princeton's important collection of Kingsley material.

${ }^{1}$ Kingsley to Huxley, 18 July 1862, Imperial College, London, Huxley Papers [hereafter HP], Gen. Letters IX (I-K), fo. 205.
} 
Christianity', Kingsley had a wide network of contacts in the world of Victorian biology and cognate disciplines. From the mid-1850s he drew away from the Christian Socialist circles of J. M. Ludlow and F. D. Maurice with whom he had established himself as a public figure. Instead he increasingly turned his attention to natural science and to history. $\mathrm{He}$ met Huxley for the first time in 1855, became a Fellow of the Linnean Society in 1857 and Regius Professor of History at Cambridge in 1860.

Kingsley engaged with Darwin both in print and in private correspondence, refusing to leave the field of natural history to supposed 'professionals'. Bernard Lightman's recent work on 'Victorian popularizers of science' includes an excellent chapter on 'clerical popularizers' such as Kingsley and George Henslow. In drawing attention to the respect and public profile enjoyed by such figures Lightman indicates the extent to which the divide between the 'professional' in his laboratory and the 'amateur' in his (or her) study was still under construction in the second half of the nineteenth century. ${ }^{2}$ This has made it easier to view Charles Kingsley's interest in evolutionary science in less schematic terms, in keeping with a broader shift away from seeing Victorian intellectual life as a battlefield in which 'faith' and 'science' were diametrically opposed. Kingsley was concerned at the widening gap between theology and science, but blamed church dogmatists as much as men of science for creating it. He felt a stronger loyalty to Darwinian 'unorthodoxy' than he did to Anglican orthodoxy.

If it has become harder to dismiss Kingsley's scientific lectures and handbooks as dilettantish, his historical lectures and novels are still seen as amateurish meddling, and his nine-year tenure of the Regius chair at Cambridge as an embarrassing case of venality (Albert, the Prince Consort supported the appointment) triumphing over professionalism. This is surprising. Owen Chadwick has shown in a sensitive appraisal of Kingsley the historian published in 1975 that there were few if any clear 'professional' alternatives to Kingsley. ${ }^{3}$ Kingsley's appointment and his wider profile as a historian were not snubs to the discipline, because that discipline had yet to lay its institutional foundations. The English Historical Review, the first British journal of its kind, only began appearing in 1886, over a decade after Kingsley's death.

Kingsley has fallen foul of the professionalization of both natural science and history not just because he was a polymath but because he sought to fashion a new Natural Theology that would fuse evolutionary biology and a 'Teutonist' view of history. History for Kingsley was the

\footnotetext{
${ }^{2}$ Bernard Lightman, Victorian Popularizers of Science: Designing Nature for New Audiences (Chicago, 2007), ch. 2.

${ }^{3}$ Owen Chadwick, 'Charles Kingsley at Cambridge', Historical Journal, xviii (1975) [hereafter Chadwick, 'Charles Kingsley'], 303-25. For Freeman's critique see [Edward Augustus Freeman], 'Mr Kingsley's Roman and Teuton', Saturday Review, 9 April 1864, pp. 446-8 (447). As Ian Hesketh notes, Freeman's 'nastiness' reached an 'almost absurd' level in such attacks: Ian Hesketh, 'Diagnosing Froude's Disease: Boundary Work and the Discipline of History in Late-Victorian Britain', History and Theory, lvvii (2008), 373-95, at p. 386.
} 
story of how a chosen race (the Teutons, who included the English) grasped its divinely ordained mission to subdue the world. Michael Young has described Kingsley's historical novel Hereward the Wake as 'national history explained as natural history'. ${ }^{4}$ This article contends that Young's observation holds for all of Kingsley's historical oeuvre, which created a 'science of history' that was both evolutionary and Providentialist. This 'science' was happy to search for 'general laws', but fought shy of the positivism and determinism it associated, perhaps unfairly, with Auguste Comte and in particular H. T. Buckle, whose History of Civilisation appeared in 1857. In opposing Buckle, Kingsley was, as Christopher Parker has shown, in good company. ${ }^{5}$ But Kingsley also held that there was more to making history a 'science' than simply adopting certain methods of archival research or pursuing it for its own sake. Unfortunately scholars have continually failed to appreciate that, to investigate what 'scientific' actually meant in the Victorian context. Hence Kingsley is excluded or sidelined in accounts describing the 'professionalization of history in Britain', stories in which Edward Augustus Freeman and William Stubbs play a more important role. ${ }^{6}$ The six volumes of Freeman's History of the Norman Conquest (1865-76) were certainly weighty tomes, and Freeman certainly claimed that his often cruel attacks on Kingsley, James Anthony Froude and other historians in the Saturday Review were simply so many demands for 'scientific' accuracy. Freeman's notorious failure to use the Public Record Office for his research as well as his fondness for loose editorializing on contemporary events nonetheless give pause.

Meanwhile in literary studies, the one field where Kingsley seems most to 'belong', his approach to evolutionary science makes him equally challenging to integrate into histories of the Victorian novel. ${ }^{7}$ For Kingsley evolution was not a 'metaphor of change' to be borrowed. It was about making analogies between evolutionary science and national history collapse into identity. Admittedly, Kingsley's 'evolution' was by no means Darwinian, and included some very curious alternatives to natural selection. Such 'misreading' is to be taken less as a sign of amateurism than as a reflection of the many competing models of

\footnotetext{
${ }^{4}$ Michael A. Young, 'History as Myth: Charles Kingsley's Hereward the Wake', Studies in the Novel, xvii (1985), 174-88, at p. 182.

5 Christopher Parker, 'English Historians and the Opposition to Positivism', History and Theory, xxii (1983), 120-45.

${ }^{6}$ Doris S. Goldstein, 'The Professionalization of History in Britain in the Late Nineteenth and Early Twentieth Centuries', Storia della Storiografia, iii (1983), 3-27. See also Thomas Heyck, The Transformation of Intellectual Life in Victorian England (1982), ch. 5; Alon Kadish, 'Scholarly Exclusiveness and the Foundation of the English Historical Review', Bulletin of the Institute for Historical Research, 61 (1988), 183-98; Rosemary Jann, 'From Amateur to Professional: The Case of the Oxbridge Historians', Journal of British Studies, xxii (1983), 122-47.

7 James C. Simmons, The Novelist as Historian: Essays on the Victorian Historical Novel (Paris, 1973), p. 38; Megan Perigoe Stitt, Metaphors of Change in the Language of Nineteenth-Century Fiction: Scott, Gaskell and Kingsley (Oxford, 1998); Francis J. Stafford, The Last of the Race: the Growth of a Myth from Milton to Darwin (Oxford, 1994).
} 


\section{AN ILLIBERAL DESCENT}

transmutation which constantly threatened to swamp natural selection in the High Victorian era.

This article is divided into four parts. The first three demonstrate how Kingsley used concepts of superfecundity, recapitulation and degradation to develop his own vision of a scientific history. Superfecundity here refers to every species's constant efforts to maximize reproduction, a trait which troubled many nineteenth-century Britons, who believed that an all-wise Creator would never abuse His powers by creating millions of surplus organisms, organisms doomed to lose out in an unseemly fight for limited food resources and living space. Recapitulation is the process by which an individual organism repeats (as part of its embryonic development in the uterus, in the case of mammals) the evolutionary development of the species as a whole. Together with theories of evolutionary regression (discussed here as 'degradation'), recapitulation encouraged a tendency to see evolution as a two-way rather than exclusively meliorist process.

The article then considers the role of 'law' in Kingsley's thought, both the 'evolution by law' that preserved a role for a divine 'law-giver' in natural science as well as the sociological and historical laws that supposedly underpinned 'scientific' history. It concludes by offering some general observations on the development of the historical discipline in Victorian Britain, and proposes that Kingsley's racialist history had a greater impact than is suggested by current assessments of 'Teutonist' historiography. While it highlights Kingsley's response to other, betterstudied Victorian historians such as Thomas Arnold, T. B. Macaulay, Thomas Carlyle, Buckle, Froude and Freeman at various points, its overarching goal is to propose how Kingsley and his racialist Providence might be reintegrated not just into discussion of British historiography, but of Victorian intellectual life in general. The privileging of a 'favoured' Teutonic race underpinned Kingsley's understanding of science, of history, and of the 'natural theology of the future' that would bring them all together. George Stocking, Nancy Stepan and Catherine Hall have noted a hardening in Victorian anthropological thought, a shift from 'monogenist' optimism stressing the unity of mankind and its shared potential towards a more 'polygenist' pessimism, which allocated very different, innate capabilities among different subgroups of homo sapiens. ${ }^{8}$ Kingsley's thought matches that shift very well.

\section{I}

As Chadwick noted, Kingsley's works found such a warm reception during his lifetime and especially in the thirty years after his death in 1875

\footnotetext{
${ }^{8}$ George Stocking, Victorian Anthropology (New York, 1987); Catherine Hall, Civilising Subjects: Metropole and Colony in the Imagination, 1830-67 (Cambridge, 2002); Nancy Stepan, The Idea of Race in Science: Great Britain, 1800-1960 (1982) [hereafter Stepan, Idea of Race], p. 4.
} 
that he can seem to epitomize the Victorian era. ${ }^{9}$ Today the shelves of many a second-hand bookshop groan under the weight of Macmillan's blue-bound edition of the works, their fly-leaves graced with Sunday School prize bookplates or a grandparent's dedication to a loved grandchild. Such popularity can seem odd, given how bloodthirsty Kingsley's works are. Philammon, Amyas, Tom, Hereward and Hartover - the heroes of Hypatia (1853), Westward Ho! (1855), The Water Babies (1862), Hereward the Wake (1866) and the unfinished Tutor's Story respectively - are all young men. Yet it is far from clear that their future duty lies in growing up. The half-century after the Reformation, Kingsley writes in Westward Ho!, was a time of intellectual freedom, but also 'of immense animal good spirits', when the English conquered a new empire 'with the laughing recklessness of boys at play'. ${ }^{10}$ These Teutonic 'forest children', as Kingsley dubbed them in his inaugural Cambridge lecture series (later published as The Roman and the Teuton) never really grow up at all. 'For good or evil they were great boys; very noble boys; very often very naughty boys - as boys with the strength of men might well be.'

The eponymous hero of Hereward the Wake is, like Amyas, a young tough who beats up a monk in the opening pages. The narrator clearly considers this a mere bagatelle (or even as a worthy act), and when Hereward's mother is persuaded by her confessor to outlaw her son he is ready. 'I only want an excuse like that for turning kempery-man - knighterrant, as those Norman puppies call it . . . and try what a man can do for himself in the world with nothing to help him ... save his wits and his good sword. ${ }^{12}$ As with all the other heroes, he heads out into the world, a case of what the Victorian sociologist and evolutionary thinker Herbert Spencer might have called 'voluntary outlawry'. ${ }^{13}$ His first call is on his uncle, who has retired to a monastery. Kingsley writes that his uncle 'could not help being strangely fond of Hereward - as was every one whom he did not insult, rob, or kill'. ${ }^{14}$ In contrast to the more docile Hereward of Walter Scott's Count Robert of Blois (1831), Kingsley's hero does not go off to join the Varangian guard in distant Constantinople. He fights the Normans to the death rather than (as Scott's figure does) waiting to receive forgiveness and restitution of his lands from William Rufus. ${ }^{15}$

For Kingsley, unlike the historians of the Scottish Enlightenment, childishness was not equivalent to barbarian rudeness, was not a

\footnotetext{
9 Chadwick, 'Charles Kingsley', 321.

${ }^{10}$ Charles Kingsley, Westward Ho! (Collins edn., 1910) [hereafter Kingsley, Westward Ho!], p. 43.

${ }^{11}$ Charles Kingsley, The Roman and the Teuton: A Series of Lectures Delivered before the University of Cambridge (1889) [hereafter Kingsley, Roman and Teuton], p. 6.

12 Charles Kingsley, Hereward the Wake (Collins edn., 1965) [hereafter, Hereward], p. 41

${ }_{13}$ Herbert Spencer, Social Statics: The Conditions Essential to Human Happiness Specified (New York, 1970) [hereafter Spencer, Social Statics], p. 185.

14 Kingsley, Hereward, p. 45.

15 For a discussion of sources and Victorian interpretations, see Andrew Wawn, The Vikings and the Victorians: Inventing the Old North in Nineteenth-Century Britain (Cambridge, 2000), pp. 318-19; Helen O’Donohue, Old Norse-Icelandic Literature (Oxford, 2004), p. 162.
} 


\section{AN ILLIBERAL DESCENT}

transitional state which all societies had to pass through on their ascent of the ladder of civilization. Kingsley took Edward Gibbon to task for drawing a parallel between the Teutons of Tacitus' Germania and 'Red Indians':

If Gibbon was right, and if our forefathers in the German forests had been like Powhattan's people... the Romans would not have been long in civilizing us off the face of the earth. No. All the notes which Tacitus gives us are notes of a young and strong race; unconscious of its own capabilities, but possessing such capabilities that the observant Romans saw at once with dread and awe that they were face to face with such a people as they had never met before. ${ }^{16}$

Though Macaulay preferred to compare his forefathers to latter-day Tahitians, otherwise he agreed with Gibbon that "nothing in the early existence of Britain indicated the greatness she was destined to attain'. Nothing could be farther from Kingsley's celebration of 'our' Teuton race as a young race. To an extent Kingsley was drawing on the 'Liberal Anglican' Providentialist approach to history championed by the late Thomas Arnold in his 1842 Introductory Lectures as Regius Professor at Oxford. There the famous headmaster Arnold had presented the Teutons as a young race that had taken the torch from the Romans, which was sprinting to the finish when all other races had given up, exhausted. Teutons were, in short, history's 'last reserve'. ${ }^{18}$

Superfecundity was one of the engines driving Kingsley's history forward. Competition was 'a universal law of living things', he reminded an audience at Sion College in 1871, and 'physical science' was proving that races were not all the same, demonstrating 'how the more favoured races ([science] cannot avoid using the epithet) exterminate the less favoured' ${ }^{19}$ To a certain extent this helped him indulge his violent streak without guilt. 'Bloodshed is a bad thing, certainly,' he told his students, 'but after all nature is prodigal of human life - killing her 20,000 and her 50,000 by a single earthquake'. ${ }^{20}$ By emphasizing reproduction superfecundity also provided Kingsley with an added argument against celibacy. Kingsley had deeply personal reasons for rejecting the early Church's view of marriage as second best to celibacy. When he first met his future wife, Francis Eliza (Fanny) Grenfell, in July 1839 she was intent on joining her three elder sisters in a Puseyite lay sisterhood at Park Village. ${ }^{21}$

\footnotetext{
${ }^{16}$ Kingsley, Roman and Teuton, p. 9. See also E. A. Freeman, 'The Effects of the Conquest of England by the Normans' (1846), John Rylands Library, University of Manchester. FA3/3/4, fo. 7. 17 Thomas Babington Macaulay, History of England in Works (12 vols., 1898), i. 4.

18 Thomas Arnold, Introductory Lectures on Modern History, Delivered in Lent Term, 1842 (2nd edn., 1843), pp. 29, 31.

19 Charles Kingsley, 'The Natural Theology of the Future', in his Scientific Lectures and Essays (1890) [hereafter Kingsley, 'Natural Theology of the Future', 313-36 (324).

${ }^{20}$ Kingsley, Roman and Teuton, pp. 13-14.

${ }^{21}$ The occasionally explicit images Charles used to persuade her to find physical as well as spiritual fulfilment in marriage to him are well-known, and need not detain us here.
} 
Kingsley saw his ideal of marriage as 'Teutonic', and his celebration of the Teuton as 'the Gothic civilizer' derived in no small part from this attribution. The 'love-match' was a concept introduced by the Teutons, he believed, one which rescued Christianity from the polygamy of the early Jews. ${ }^{22}$ The 'Romance or Popish races of Europe' had never, he claimed, espoused the 'Teutonic' love match. ${ }^{23}$ The Roman Catholic Church's imposition of father confessors alienated wives from their husbands, challenging the husband's physical and moral authority within the marriage bond and sowing shame and dissension in the mind of the wife..$^{24}$ In the Saint's Tragedy (1848) it is the Teuton character, Walter of Avila, who urges the king of Hungary to rule manfully and to make a woman of his betrothed Elizabeth. ${ }^{25} \mathrm{He}$ is contrasted with Conrad, Elizabeth's confessor, described as typical of those 'sleek passionless men, who are too refined to be manly, and measure their grace by their effeminacy'. ${ }^{26}$

While Conrad's influence successfully prevents the wedded couple from consummating their marriage by portraying sex as carnal sin, he himself is later discovered to be racked by passionate feelings towards Elizabeth ${ }^{27}$ Though impotent, these passions are not without their outlet. Such celibate confessors exact terrible compensation in the gruesome dismemberments to which they subject the objects of their shameful lusts. On her deathbed Elizabeth accurately predicts that her body will be harvested for relics, and asks Conrad to protect the integrity of her corpse. He refuses. Kingsley's focus on this ghastly aspect of Elizabeth's death anticipates the violent dismemberment and rape of another martyr, the Alexandrian philosopher Hypatia, in the novel of the same name. ${ }^{28}$ This, for Kingsley, is what happens when 'superstition' forces humans to 'stultify the primary laws of their being' by remaining celibate. ${ }^{29}$

\section{II}

Superfecundity pushes living things to extend their territory, destabilizing neighbouring ecosystems. For Kingsley, the Teutons were an everexpanding race. Migration was of their very nature, it marked them out from other races. 'The Teutons were and are a strange people; so strange

\footnotetext{
${ }^{22}$ Charles Kingsley, Alexandria and her Schools: Four Lectures Delivered at the Philosophical Institution, Edinburgh (Cambridge, 1854) [hereafter Kingsley, Alexandria], p. 153.

${ }^{23}$ Cited in Fanny Kingsley, Charles Kingsley: His Letters and Memories of His Life (9th edn., 2 vols., 1881) [hereafter Kingsley, Charles Kingsley], i. 103.

${ }^{24}$ Kingsley, Roman and Teuton, p. 202. See also Kingsley to Stapleton, n.d. [Friday] and 26 May 1847, Princeton University Library, Kingsley Papers [hereafter KP], Box 14, Folder 10.

${ }_{25}$ Charles Kingsley, The Saint's Tragedy, or the True Story of Elizabeth of Hungary, Landgravine of Thuringia, Saint of the Romish Calendar (1848) [hereafter Kingsley, Saint's Tragedy], p. xix.

${ }^{26}$ Ibid., p. 82.

27 Ibid., p. 208

${ }^{28}$ Charles Kingsley, Hypatia, or New Foes with an Old Face (1895) [hereafter Kingsley, Hypatia], p. 453.

${ }_{29}$ Ibid., p. 253.
} 


\section{AN ILLIBERAL DESCENT}

that they have conquered - one may almost say they are - all nations which are alive upon the globe. ${ }^{30}$ Any race which found itself in the path of the Teutons faced a choice: to be assimilated or disappear. As Celts, the Irish were doomed to come off second best in any struggle with Teutons like the English. In Hereward the Irish are compared to Maori, as one of a series of low races of human unable to improve physically or technologically without outside help. Ireland's ports, for example, are all the result of the Danes. Their race was insufficiently evolved to have a real history, Kingsley believed. What history the Irish did claim was 'one dull and aimless catalogue of murder and devastation' ${ }^{31}$

Kingsley drew on early nineteenth-century French theories of dégénérescence to develop 'my degradation theory', according to which races disappeared by a sort of reverse evolution, to the point where they were no longer to be counted as human life. Degradation came to fascinate Kingsley c.1860, and became something of an obsession. The 'manhood' of a race consisted in 'the defiance of circumstances', yet there were some races (the 'Chinese', the 'negro', the Turk) unable to stand defiance, to pull themselves out of the slough of 'circumstances'. ${ }^{32}$ In theory such races could escape the harshness of this sentence by availing themselves of another evolutionary concept: recapitulation, the process by which creatures could move back up the ladder. In practice Kingsley did not consider this very likely in the case of those races.

Assimilation fascinated Kingsley. His Teutons only became fit to govern the world when they learned 'discipline and civilization' from the Roman armies they fought or in which they served as mercenaries. ${ }^{33}$ In the same way the doomed Saxons in Hereward are presented as lacking that discipline and coordination which enabled the physically weaker Normans to triumph over them. The boyish playful energy of the Teutonic race needed direction. Happily this race was uniquely gifted in being able to take on a different races' positive characteristics without diluting its essence in any way. Chapter 8 of Westward Ho! begins with Kingsley's account of the ornate ritual of the 'Brotherhood of the Rose', a mock-chivalric order made up of Bideford boys linked by their shared love for the local beauty, Rose Salterne. The narrator asks his reader's forgiveness for the florid language in which they couch their affection:

Let us not only see in their commercial and military daring, in their political astuteness, in their deep reverence for law, and in their solemn sense of the great calling of the English nation, the antetypes, or rather the examples, of our own: but let us confess that their chivalry is only another garb of that beautiful tenderness and mercy which is now, as it was then, the twin sister of English valour; and even in their oft extravagant fondness

${ }^{30}$ Kingsley, Roman and Teuton, p. 54.

31 Kingsley, Hereward, p. 92.

32 Charles Kingsley, Three Lectures Delivered at the Royal Institution, on the Ancien Regime as it Existed on the Continent Before the French Revolution (1867), p. 89; Kingsley, Alexandria, p. xvii.

${ }^{33}$ Charles Kingsley, The Hermits (Sunday Library for Household Reading, 1868), p. 5. 
of Continental manners and literature, let us recognise that old AngloNorman teachableness and wide-heartedness, which has enabled us to profit by the wisdom and the civilisation of all ages and of all languages, without prejudice to our own distinctive national character. ${ }^{34}$

Kingsley was aware of the paradoxical nature he was attributing to the Teutons, but would remain unrepentant. Edward Bulwer's Harold (1848), which he admired, had described the Vikings (one of the 'AngloSaxon' peoples) as 'wonderfully pliant and malleable in their admixtures with the peoples they overran'. 'This is their true distinction from the stubborn Celt,' he added, 'who refused to mingle, and disdains to improve. ${ }^{35}$ Shortly before his death Kingsley toured America, where he addressed his audiences as the next generation of Teutonic frontiersmen: manly, free and teachable. 'I do not hesitate to say that, paradoxical as it may seem, the most original races - those who have succeeded best and left their stamp most broadly and permanently on the human race - have also been the most teachable.' 36

No historical episode gave more satisfaction to assimilationists than the Norman Conquest. As Billie Melman has noted, the way in which 1066 was elevated to 'an iconic year' in a 'national struggle', 'more important than either 1642 or 1688 ... [was] a challenge to the hegemonic Whig version of the past'. ${ }^{37}$ Macaulay had given the whole eleventh century less than a page in his History of England (1848-55). Although the Norman Conquest was traditionally understood in terms of the imposition of a 'Norman yoke' around the necks of free Saxons, assimilationists presented it more as a case of conquest in reverse. The Teutons lost the battle, but lived to fight another day. 'The conquest of England by the Normans was not one of those conquests of a savage by a civilised race,' Kingsley argued in his American lectures, 'or of a cowardly race by a brave race, which results in the slavery of the conquered, and leaves the gulf of caste between two races' ${ }^{38}$ This picture was very different from that found in Macaulay. ${ }^{39}$

Set in East Anglia in the eleventh century, at first glance Hereward the Wake seems to be a tale of total conquest, to which Hereward's Saxon band, the 'last of the English', offer token resistance for a time, before being eliminated in a final showdown in the fens. Having lost his people, Hereward is left defending a landscape surrogate. Hereward takes his final stand on the edge of memory, almost falling out of his assigned role in a landscape that is itself on the verge of melting away. Like Carlyle's

\footnotetext{
34 Kingsley, Westward Ho!, pp. 178-9.

35 Sir Edward Bulwer-Lytton, Harold: The Last of the Saxon Kings (1848) [hereafter Bulwer-Lytton, Harold], p. 33.

${ }^{36}$ Charles Kingsley, Lectures Delivered in America in 1874 (1875) [hereafter Kingsley, American Lectures], p. 2.

${ }^{37}$ Billie Melman, 'Claiming the Nation's Past: The Invention of an Anglo-Saxon Tradition', Journal of Contemporary History, xxvi (1991), 575-95 (581).

${ }^{38}$ Kingsley, American Lectures, p. 83.

39 T. B. Macaulay, History of England, 6 vols. (1898), i. 15.
} 


\title{
176 AN ILLIBERAL DESCENT
}

\begin{abstract}
1 Besenval in The History of the French Revolution, Hereward threatens to march off 'towards infinite space': ${ }^{4}$

As the sun sank lower, higher rose the mist; and the isle grew more and more faint, vaporous, dreamy, as fen-distances are wont to be. Was it not about to fade away in reality; to become a vapour, and a dream, and leave him alone, and free? Earls, knights, housecarles, monks, seemed all becoming phantoms, fading with their fading cause. Was it worth while to fight, to die, for them, for anything? What was William [the Conqueror] to him? What was England? ${ }^{41}$
\end{abstract}

It is as if Hereward is actively conceiving 'England', his mind summoning it into existence.

Freeman also shared this fascination for landscape as a stage for history, and so describes in his History of the Norman Conquest how William the Conqueror 'called . . . into being' the city of Lillebonne (formerly the Roman city Juliobona) 'as if expressly to become the scene of this remarkable meeting' between Harold and himself. ${ }^{42}$ There are, he insists, 'spots which nature seems to have marked out as the almost necessary place of some memorable deed' ${ }^{43}$ There are other echoes of Freeman in Hereward's final tableau, which features the Norman Richard de Rulos, described as the first to set about draining the fens. Hailed by the narrator as 'the first of the new English' and a descendant of Hereward (his daughter having married into the Norman nobility after his death) it is thanks to Richard that the land of the 'last of the English' will re-emerge from the fenland mists. ${ }^{44}$ 'First' and 'Last' of the English, Richard and Hereward end up buried next to each other, just as the 'last of the English' (Edward the Confessor) and the 'first of the English' (Harold) lie together (if only temporarily) in Waltham Abbey in Freeman's Norman Conquest. ${ }^{45}$ In both cases conquest and death are unmasked as assimilation and rebirth.

In Harold, the Last of the Saxons (1848) Bulwer has his hero describe the 'Anglo-Danes' of East Anglia as having 'freer laws and hardier manners' that 'are gradually supplanting, or rather regenerating, our own' ${ }^{46}$ This slippage between 'supplanting' and 'regenerating' is typical of both Freeman and Kingsley's account of the Conquest. But can one be an assimilationist and also a racialist? Their position seems fatally flawed by internal paradox. Kingsley, however, found a way out by means of another concept familiar from nineteenth-century evolutionary biology: recapitulation.

\footnotetext{
40 Thomas Carlyle, The French Revolution: A History (3 vols., 1898), i. 199.

41 Kingsley, Hereward, p. 302.

42 Edward Augustus Freeman, The History of the Norman Conquest of England (abridged edn., Chicago, 1974) [hereafter Freeman, Norman Conquest], p. 81.

43 Ibid., p. 124.

${ }^{44}$ Kingsley, Hereward, p. 412.

45 Freeman, Norman Conquest, p. 217.

${ }^{46}$ Bulwer-Lytton, Harold, p. 139.
} 


\section{III}

As Peter Bowler has demonstrated, the publication of Origin of Species in 1859 served as a catalyst rather than as the basis of a new Darwinian consensus. 'Once convinced that evolution did occur' men of science 'turned their backs on Darwin's message and got on with the job of formulating their own theories of how the process worked. ${ }^{37}$ Kingsley revelled in watching Darwin's ideas spread, and Darwin himself recognized that he had a useful ally in Kingsley. 'It is very interesting and surprising to me that you find at Cambridge after so short an interval a greater willingness to accept the views which we both admit', Darwin wrote to Kingsley in late 1867. 'I do not doubt that this is largely owing to a man so eminent as yourself venturing to speak out. ${ }^{48}$ But Kingsley clearly did not follow Darwin religiously. After a merry house party at Lord Ashburton's spent discussing Huxley and Darwin with the duke of Argyll, Monkton Milnes and Bishop of Oxford Samuel Wilberforce, Kingsley wrote to Huxley reiterating his delight at Darwin's fame, but added an important caveat: 'You cannot conceive how Darwin's views are spreading - with - of course, demurrers and reconsiderations, quite necessary in so great and new a vista of thought. ${ }^{49}$ Darwin had served science and faith by stirring up speculation, by asking more questions than he solved. For Kingsley good science was that which replaced comforting certainties with unsettling hypotheses, that multiplied mysteries.

When in 1869 Huxley announced his discovery of the protoplasm (which he dubbed Bathybius Haeckelii) in a sample of mud collected from the sea floor by HMS Challenger, Kingsley was delighted. Huxley's 'physical basis of life' was the clay out of which the mind of God could summon any and all life forms, a holy font of life to which all overevolved lifeforms could return, bathe and come out clean again. This multi-purpose fluid was a useful solvent for over-engineered, mechanistic chains of inheritance. It showed, he wrote Huxley, that whatever agency had turned inorganic into organic life was still in operation now. "And when [Richard] Owen propounded some such theory to me 3-4 years ago, I agreed to its probability - and told him laughing that I liked it because he went further than Darwin. ${ }^{50}$ Kingsley recognized that Christianity had to choose between investing every new discovery with divine

\footnotetext{
${ }^{47}$ Peter J. Bowler, The Non-Darwinian Revolution: Reinterpreting a Historical Myth (Baltimore, 1988) [hereafter Bowler, Non-Darwinian Revolution], p. 67.

${ }^{48}$ Darwin to Kingsley, 13 Dec. 1867, Pierpont Morgan Library, New York, MA6420.

49 Kingsley to Huxley, 28 Feb. 1862, HP, Gen. Letters IX (I-K), fo. 203. See also Darwin to Maurice, n.d. [1863]. British Library Additional Manuscript [hereafter BL Add. Ms] 41297, fo. 147. ${ }^{50}$ Kingsley to Huxley, 18 May 1863. HP, Gen. Letters IX (I-K), fo. 223. Kingsley's view of the protoplasm anticipates that taken by Eliza Brightwen in her popular science writing in the 1890s. Lightman, Victorian Popularizers, p. 449. Kingsley may be referred to Owen's theory of parthenogenesis here, but that would have been much older than ' 3 or 4 years ago', as Owen's Parthenogenesis appeared in 1849. Adrian Desmond, Archetypes and Ancestors: Palaeontology in Victorian London, 1850-1875 (1982) [hereafter Desmond, Archetypes and Ancestors], p. 37.
} 


\section{AN ILLIBERAL DESCENT}

agency or retreating with its Creator God to those parts of the universe scientists had yet to investigate. As he put it to the entomologist Henry Bates in 1863, 'a convert to Darwin's views', could view the world as being 'like an immensely long chapter of accidents', but it was 'really ... a chapter of special Providences of Him without whom not a sparrow falls to the ground'. 51

Huxley's work on budding in coelenterates (aquatic invertebrates such as sea squirts) provided further indications to Kingsley that the latest science was on track to reconnect with theology, or, rather, to provide the basis of a 'natural theology of the future'. The way in which polyps could reproduce by 'budding' made biblical references to mankind's Adamcentred lineage appear more rather than less credible. 'Darwin's law of heredity transmission is all in the same direction', Kingsley wrote to Maurice, 'the Pauline idea of the Old Adam has become under Darwin's hands a scientific and provable fact. ${ }^{52}$ Kingsley later asked Huxley to recommend reading on spermatozoa, with a view to learning more about the relative importance of sperm and egg in inheritance. He interpreted new discoveries that downplayed the role of the sperm in sexual reproduction as providing 'more and more reason to believe that the birth of a child without a father is a natural possibility'. ${ }^{53}$

Recapitulation, however, was to have a far greater impact on Kingsley's theological, scientific and historiographical thought. The concept provides the narrative framework for Kingsley's best-known work, The Water Babies, as it did for other authors, such as George Eliot. ${ }^{54}$ Kingsley's 'parable' was part of his larger project of 'working out points of Natural Theology, by the strange light of Huxley, Darwin and Lyell'. ${ }^{55}$ The tale's hero, Tom the chimneysweep, is led to acknowledge his dirty nature by seeing little Ellie. In seeking to clean himself he drowns, is transformed into an eft and then climbs back up the evolutionary ladder, recapitulating the original evolution of mankind under the stern tutelage of Mother Nature herself. Set within the Water Babies is the cautionary fable of the Doasyoulikes, who evolve backwards into apes after moving from the Land of Hard Work to the carefree consumer utopia of the Happy-Go-Lucky Mountains.

Degradationism provided another way in which Kingsley could accept the destruction of races as Providential, and join Carlyle and Froude in sneering at what the latter called 'that weak watery talk of "protection of

\footnotetext{
${ }^{51}$ Kingsley to [Henry Bates], 13 April 1863. My identification of Kingsley's correspondent as Bates is based on references to the correspondent having published a paper on 'mocking' (i.e. mimicry) in South American butterflies, as Bates in fact did (KP, AM18153). See also Kingsley, Charles Kingsley, ii. 254.

52 Kingsley to Maurice, n.d. [1863?], BL Add. Ms 41297, fo. 153.

53 Kingsley to Maurice, n.d. [1863], BL Add. Ms 41297, fo. 147.

${ }^{54}$ Gillian Beer, Darwin's Plots: Evolutionary Narrative in Darwin, George Eliot and NineteenthCentury Fiction (2nd edn., Cambridge, 2000), p. 99.

${ }_{55}$ Kingsley to Maurice, n.d. [1863], BL Add. Ms 41297, fo. 147.
} 
aborigines", 56 Not all his friends, however, were of the same mind. Kingsley's defence of Rajah Brooke's genocidal policies towards the dyaks of Borneo caused a rupture in his relationship with J. M. Ludlow, who had been one of Kingsley's closest allies back in the 1840s, when they had developed Christian Socialism as a riposte to the rise of Chartism. Ludlow's revulsion for Brooke's actions drew a strong response from Kingsley, who urged him to 'read history; look at the world, and see whether God values mere physical existence'. ${ }^{57}$ In the same way the disastrous fate of the French in the Franco-Prussian War led Kingsley to suggest 'that there might be cases in wh[ich] whole races or communities had fallen so low, that it was better for the whole world - and probably for them in another life - that they should [be] exterminated'. ${ }^{58}$

Part of this shifting of humanity's parameters was motivated by pride, by a desire to escape the humiliation of associating ourselves as 'humans' with creatures that are, apparently, far less intelligent than us. It was surely better, Kingsley argued, to believe that 'savages' are not humans like us when the former lack 'wit enough to discover any better food than ants and clay'. ${ }^{59}$ Shifting the parameters of 'human life' also helped Kingsley get round the anti-democratic hero-worship of Carlyle, by arguing that the great man was 'the normal man, as approaching more nearly than his fellows to the ... standard of a complete human character'. The 'new science of little men', which claimed to be able to observe and predict the movements of the 'average man' in the past, present and future was not a science of man, but extrapolated from 'a crowd of dwarfs and cripples'. ${ }^{60}$

Kingsley's belief in the transmigration of souls (metempsychosis) and degradation implied a unitary personality or soul that passed from one body to another. But this metempsychosis had implications for mankind's future state, as well as its past and present. It confirmed Kingsley's refusal to believe in hell and eternal damnation, in a steady state of suffering ordained by divine judgment. ${ }^{61}$ In a way Kingsley's belief in recapitulation and metempsychosis implicated him in a constant deferral of final judgment of an immaterial yet eternal soul in favour of regular chastisement of a kind of soul that was constantly bleeding from the spiritual into the physical realm, and which could be found in all forms of life, not just human beings.

Without this 'big ditch' separating men from apes Kingsley was able to accommodate and even welcome Huxley's heresies about having an ape

\footnotetext{
${ }^{56}$ Froude, 'England's Forgotten Worthies' (originally Westminster Review, 1853) in Froude, Short Studies on Great Subjects (1st ser., 2nd edn., 1867), 294-333 (305).

${ }_{57}$ Cited in Kingsley, Charles Kingsley, i. 340-1.

58 Kingsley to Arthur Helps, 30 March 1871, KP, AM 17335.

${ }^{59}$ Kingsley, Westward Ho!, p. 448.

${ }^{60}$ Kingsley, Roman and Teuton, p. 332.

${ }^{61}$ Kingsley, Charles Kingsley, i. 10; Kingsley, 'For the Private Consideration of the Committee', n.d. Charterhouse Archives, Godalming, Surrey. ACC0431/5; John Henry Newman, Tract Ninety, or Remarks on Certain Passages in the 39 Articles [1841] (1933), pp. 29-31.
} 


\section{AN ILLIBERAL DESCENT}

1 for a grandfather. When Huxley wrote Kingsley in May 1863 challenging him on just this point Kingsley was careful to set him straight:

I never said men had souls and apes had not. I sh[oul]d rather put it - that souls had men, than men souls: but be that as it may, I have every reason to suppose that an ape has a soul, if a man has one; and every other being or organized thing - only of a lower organization, according to its degree. There is not a word in Scripture . . wh[ich] denies that. ${ }^{62}$

Kingsley retains a belief in the disposable soma, but refuses to attach moral or aesthetic judgment to 'disposable'. The body is not a repellent or insignificant husk, and certainly not a sinful tempter.

The body was a faithful representation of the soul within it, and its limbs or 'members' were the tools with which the soul fitted itself for its next life in a different body. This could be seen as 'inheritance of acquired characteristics', as in that model of non-Darwinian evolution first proposed by the famed French naturalist Lamarck. This leaching of moral habits into physiological nature can also be found in later writings by Herbert Spencer, Alexander Bain and Henry Maine. As Stefan Collini has shown, their concept of 'character' possessed a similar 'diluted Lamarckianism' by which 'habit leaves deposits in the nervous system itself'. They exhibited 'a fascination with the idea that in properly exercising the muscles of the will the individual might be acquiring a new capacity that could operate instinctively on future occasions ... and determine the behaviour of future generations'. ${ }^{63}$ In an 1876 essay in the journal Mind, Spencer could thus speak of 'the cumulative effects of habit on function and structure'. ${ }^{64}$

In an 1879 essay entitled 'The Soul, and the Theory of Evolution', the science writer Arabella Buckley explained how apparently conflicting concepts could be reconciled if evolution was properly understood

as a compound of inheritance and the accumulated experiences of each new individual. Reminiscence, ancestral likeness, race characteristics, animal passions, the struggle between the higher good, and the lower nature in which mere propensities have become conscious evil when higher possibilities have been developed - all these are explicable on the theory of evolution. ${ }^{65}$

In The Water Babies Tom's various metamorphoses on the road back to humanity are the reward for having developed moral faculties. Several bodies house his unitary soul as it improves. The transmigration of the soul from one body to another or metempsychosis is therefore another

\footnotetext{
62 Kingsley to Huxley, [23 May 1863], HP, Gen. Letters IX (I-K), fo. 235.

${ }^{63}$ Stefan Collini, Public Moralists: Political Thought and Intellectual Life in Britain, 1850-1930 (Oxford, 1991), pp. 98 (quote), 275.

${ }^{64}$ Herbert Spencer, 'The Comparative Psychology of Man', in Spencer, Essays: Scientific, Political, and Speculative (3 vols., 1891) [hereafter Spencer, Essays], i. 363.

65 'A.B.' [Arabella Buckley], 'The Soul, and the Theory of Evolution', University Magazine, iii (1879), 1-10 (10).
} 
important concept for Kingsley, who wrote proudly to the physiologist George Rolleston of 'my theory that souls secrete bodies' ${ }^{66}$

Buckley's idea of transmigration emerged from her interest in spiritualism, a movement to which Kingsley was almost entirely indifferent. Animal souls and transmigration were, as Oppenheim has noted, not part of the spiritualist mainstream. ${ }^{67}$ There is no evidence that Kingsley drew on Hindu notions of karma in this thought. Kingsley's ideas came instead from his 1849 reading of Pierre Leroux and his circle of French socialist thinkers, to whom he was most likely introduced by Ludlow. ${ }^{68}$ Like Kingsley, they sought solidarity with the workers, reviled nostrums of political economy and advocated universal manhood suffrage without seeking (as Charles Fourier did) to purge society of family, property and a Christian morality. Like Kingsley, they refused to believe in eternal damnation, and instead held that the self went through multiple lives.

'To live is to die in one form in order to be reborn in another form', as Leroux put it in his De l'humanité (1840). ${ }^{69}$ Reynaud's entry for 'Ciel' in the Encyclopédie nouvelle (1836-40) that he edited with Leroux clearly inspired Kingsley:

Thus the soul, which passes from one journey to another, leaving its first body for a new body, constantly changing its residence and its exterior, pursues under the rays of the Creator, from transmigration to transmigration and metamorphosis to metamorphosis, the palingenetic course of its eternal destiny . . . Birth is not a beginning, it is merely a change of body. ${ }^{70}$

In the context of contemporary French comparative anatomy Leroux and Reynaud were firmly on the side of the transmutationist Geoffroy St. Hilaire (who contributed to the Encyclopédie nouvelle) not that of Cuvier who believed, not in the limitless and infinitely variable forms of life, but that all life was grouped around certain model forms, or archetypes.

Rather than being deferred until the Apocalypse, God's judgement of man was constant. To use the terminology of early Victorian geology, it was uniformitarian rather than catastrophist; a story of ongoing, routine activity, rather than long periods of inactivity interrupted by cataclysmic change. Metempsychosis made this constant judgement possible. Degenerated life forms were paying the price for their misbehaviour in a previous life, but recapitulation held out the promise of redemption. ${ }^{71}$ With multiple lives at his disposal Kingsley could reconcile the stern Judge of the Old Testament, punishing unto several generations, with the

\footnotetext{
${ }^{66}$ Kingsley to Rolleston, 12 Oct. 1862; Kingsley, Charles Kingsley, i. 133-4. See also Kingsley to Huxley, 17 [May?] 1865, HP, Gen. Letters IX, fo. 221.

${ }^{67}$ Janet Oppenheim, The Other World: Spiritualism and Psychical Research in England, 1850-1914 (Cambridge, 1985).

${ }_{68}$ J. M. I. Klaver, The Apostle of the Flesh: A Critical Life of Charles Kingsley (Leiden, 2006), p. 188.

${ }^{69}$ Lynn Sharp, 'Metempsychosis and Social Reform: The Individual and the Collective in Romantic

Socialism', French Historical Studies, xxvii (2004), 349-79, at p. 368.

${ }^{70}$ Cited ibid., 369

71 Kingsley to Huxley, 21 Sept. 1860, HP, Gen. Letters IX (I-K), fo. 162.
} 


\section{AN ILLIBERAL DESCENT}

all-merciful Christ. God was 'too good an instructor to lose finally any of his pupils'. ${ }^{72}$

\section{IV}

Though correspondence with Huxley and other 'strictly scientific men' provided him with a certain amount of scientific companionship, Kingsley often felt painfully alone and exposed in his project of rewriting natural theology. As he wrote to Rolleston a few years later, just now [botanist Joseph] Hooker seems to think Natural Theology impossible: I have hoped for a rational and scientific one for years past, and worked humbly at its foundations: but I have no fellow worker, or even a fellow talker. ${ }^{73}$ This led him to confide in Huxley in an exchange of remarkably frank letters lasting from 1860 to 1864, sparked off by Huxley's despair at the sudden loss of his three-year-old son Noel. ${ }^{74}$ Read alongside key theorists of 'evolution by law' such as Argyll and Mivart, they allow a unique perspective on the ontological status of 'law' in mid-Victorian theology, science and history. 'Law' could be perceived in different ways: as descriptive, prescriptive or as a manifestation of 'will-force'.

Huxley began by addressing Kingsley the Anglican clergyman in characteristically aggressive terms. 'Understand that this new school of prophets is the only one that can work miracles - the only one that can eventually appeal to nature for evidence that it is right.' The Church would be 'shivered into fragments by the advancing tide of science' if it was left to the direction of 'men like [Samuel] Wilberforce'. ${ }^{75}$ Kingsley agreed entirely, and sought to encourage the Anglican clergy to inform themselves about science. Which particular scientific questions young clergy should read up on was clear: 'I mean questions of Embryology and questions of Race. ${ }^{, 76}$ Far from representing a threat or innovation, such activity formed part of a scientific and philosophical tradition (the eighteenth-century philosopher-divines Joseph Butler, George Berkeley and William Paley) of which the Anglican Church could be proud.

Kingsley may have been surprised to find Huxley placing himself in the selfsame tradition, as a devotee of Butlerian probabilism. ${ }^{77}$ Huxley had, he explained to Kingsley, a very weak concept of 'law':

I know nothing of necessity - abominate the word Law (except as meaning that we know nothing to the contrary) - and am quite ready to admit that there may be some place . . where $2+2=5$ and all bodies naturally repel one another instead of gravitating together - I don't know whether matter

72 Kingsley, Charles Kingsley, i. 57.

73 Kingsley to Rolleston, 10 Sept. 1868, KP, AM81-116.

${ }^{74}$ See especially Kingsley to Huxley, 26 Sept. 1860, HP, Gen. Letters IX, fo. 180. Huxley to Kingsley, 22 Sept. 1860, HP, Gen. Letters IX, fo. 169.

${ }^{75}$ Huxley to Kingsley, 22 Sept. 1860. HP, Gen. Letters IX, fo. 169

${ }^{76}$ Kingsley, 'Natural Theology of the Future', p. 322.

77 Huxley to Kingsley, 5 May 1863, HP, Gen. Letters IX, fo. 216. 
is anything distinct from force - I don't know that atoms are anything but pure myths . . . in fact if I am pushed, metaphysical speculation lands me exactly where your friend Raphael [in Hypatia] was when his bitch [Bran] pupped - in other words I believe in [Sir William] Hamilton[,] [Henry] Mansel and Herbert Spencer so long as they are destructive and I laugh at their beards as soon as they try to spin their own cobwebs. Is this basis of ignorance broad enough for you? This universe is, I conceive, like to a great game being played out and we poor mortals are allowed to take a hand - by great good fortune the wiser among us have made out some few of rules of the game, as at present played, we call these 'laws of nature' and honor them because we find that if we obey them we win something for our pains - the cards are our theories and hypotheses the tricks . . But what sane man would endeavour to solve this problem: given the rules of a game or the winnings to find whether the cards are made of pasteboard or gold leaf?... Who knows when the great Banker may sweep away table and cards and all - and set us learning a new game? ${ }^{78}$

It is difficult to square this Huxley with the fearsomely self-confident figure presented by Adrian Desmond, which is perhaps why he doesn't discuss the correspondence in any detail. ${ }^{79}$

The Huxley of both these letters as well as Man's Place in Nature (1863) seems a world away from the more strident Huxley of the 1880s and 1890s. In Man's Place Huxley speaks of scientific knowledge expanding within the confines of a paradigm until it no longer fits, whereupon 'the human larva' sloughs off its 'cracking integument' and grows a new one. He encourages his audience to help 'ease' off this shell. ${ }^{80} \mathrm{He}$ is measured in his praise of Darwin's hypothesis and even in the Prolegomena (1894) to Evolution and Ethics he insists that evolution was not an explanation of the cosmic process but merely a generalized description of the method and results of that process. ${ }^{81}$ For all his stridency, Huxley never budged from the 'theological agnosticism' of the sort advanced by Mansel in his 1858 Bampton Lectures, and ridiculed the variety of 'laws' being proposed to explain this or that aspect of evolution. ${ }^{82}$ Seen in this light, all natural science was natural history, was just 'one damn thing after another'. ${ }^{83}$

\footnotetext{
78 Huxley to Kingsley, 22 May 1863, HP, Gen Letters, IX, fo. 229.

79 Adrian Desmond, Huxley: Devil's Disciple (1994).

80 The Major Prose of Thomas Henry Huxley, ed. Alan P. Barr (Athens, GA, 1997) [hereafter Barr (ed.), Huxley], p. 66.

${ }^{81}$ Barr (ed.), Huxley, pp. 105, 287. On this issue, see Michael Ruse, 'Thomas Henry Huxley and the Status of Evolution as a Science', in Thomas Henry Huxley's Place in Science and Letters: Centenary Essays, ed. Alan P. Barr (1997), pp. 140-58.

${ }^{82}$ Huxley, 'Scientific and Pseudoscientific Realism' [orig. Nineteenth Century, April 1887] in Collected Essays (9 vols., 1893-4), v. 59-87 (77). Huxley later described such laws as 'a kind of angels or demiurgoi, who, being supplied with the Great Architect's plan, were permitted to settle the details among themselves'. He dubbed Argyll's The Reign of Law 'a sort of "summa"' of this 'pseudoscientific philosophy' (Huxley, 'Science and Pseudo-science', The Nineteenth Century, cxxii (April 1887), 481-98, at p. 491).

${ }^{83}$ For a discussion of this famous quote from H. A. L. Fisher, see G. R. Elton, The Practice of History (2nd. edn., Oxford, 2002), p. 36.
} 


\section{AN ILLIBERAL DESCENT}

As Frank Turner has noted, many Victorian men of science regarded scientific laws as 'governing nature or as being imperatives in nature. This view of law represented a transitional stage between a juridically oriented concept of law and the early twentieth-century descriptive concept. ${ }^{84}$ Huxley and Spencer must count as 'early twentieth-century' in this schema, but otherwise Turner is correct: evolutionary laws were viewed as prescriptive, as self-enacting cogs in the 'cosmic process'. This is what upset Argyll and Mivart. 'Natural selection' frustrated Argyll because 'the word, "Natural", prefixed to the word "Selection", is as inseparably bound up with the idea of mechanical necessity, or of natural and inevitable consequence. And the whole aim and object of the phrase is to substitute for the action of a free and intelligent Will the blind results of accident and mechanical necessity. ${ }^{85}$ The coupling of 'mechanical necessity' and 'accident' is curious, but may reflect an eagerness to fend off a watchmaker God: one whose intelligence created a self-regulating system that operated by 'mechanical necessity' and thereafter left him aloof and uninvolved.

The key texts for 'evolution by law' were Argyll's Reign of Law (1867) and Mivart's On the Genesis of Species (1871). Both pointed to opposable thumbs, eyes, brains and the faculty of speech as cases where natural selection could not explain what they considered organs that 'anticipated' the future needs of the creature concerned (an argument William Paley had made in his Natural Theology of 1802), or which involved the parallel emergence of distinct features none of which in isolation were of any benefit to the creature. Some higher intelligence must have been guiding transmutation in a particular direction. To Argyll laws became instruments through which God manifested his power over the universe, 'essential implements or tools in the hands of Will'. ${ }^{86}$ Mivart took this 'Will' ever further, proposing 'that all force may be will force; and thus, that the whole universe is not merely dependent on, but actually is, the WILL, of higher intelligences, or of one Supreme Intelligence' ${ }^{87}$ The guided 'evolution by law' of Argyll helped many evolutionists speed up the process sufficiently for them to be able to accommodate it with the recalculation of the earth's age unleashed by the work of the physicist Lord Kelvin (which suggested that the earth was not in fact millions of years old) ${ }^{88}$ Admittedly, discerning exactly how these different types of 'laws of creation' are supposed to work can be difficult. As Bowler has noted, they were popular precisely because they fudged issues. ${ }^{89}$

\footnotetext{
${ }^{84}$ Frank Turner, 'Victorian Scientific Naturalism and Thomas Carlyle', in Turner, Contesting Cultural Authority: Essays in Victorian Intellectual Life (Cambridge, 1993) [hereafter Turner, Victorian Intellectual Life], p. 148.

${ }^{85}$ Argyll, What is Science? (Edinburgh, 1898), pp. 57-8.

${ }^{86}$ Ibid., p. 29.

${ }^{87}$ George St. Jackson Mivart, On the Genesis of Species (1871), p. 280.

${ }^{88}$ Desmond, Archetypes and Ancestors, p. 180.

${ }^{89}$ Peter J. Bowler, Evolution: The History of an Idea (rev. edn., Los Angeles, 1989), p. 144; Bowler, Non-Darwinian Revolution, p. 63.
} 
In the narrower context of palaeontology Argyll went on to propose a principle of degradation in works such as Primeval Man (1869), one that balanced regression against progression. 'Man's capacities of degradation stand in close relation', Argyll wrote, 'and are proportionate, to his capacities of improvement. ${ }^{90}$ Whether as a 'law' or a 'principle', 'degradation' or 'degeneration', Argyll's concept grew in stature the years after Kingsley's death. Anton Dohrn advanced his own 'degeneration principle' to Darwin, arguing that it had to be incorporated in Darwinian zoology. ${ }^{91}$ Even the co-discoverer of natural selection, Alfred Russel Wallace, came out in support at the 1876 meeting of the British Association for the Advancement of Science (BAAS), and three years later Ray Lankester published his Degeneration, which showed how creatures presented with a glut of food degenerated, like real-life Doasyoulikes. ${ }^{92}$ As Kevles and Pick have shown, from the 1880s onwards degradation became less of a brake that intermittently interrupted evolution's upward progress and more like a gravitational force that evolution struggled in vain to escape..$^{93}$

Kingsley seems to have started out with a descriptive model of law and become more prescriptive over time. At the time of his correspondence with Huxley, Kingsley saw 'law' as essentially descriptive rather than causative, as 'customs of matter' ${ }^{94}$ Evolution had not replaced the reign of God with the reign of law, but brought us closer to understanding God's power as something dynamic that invested all of creation all of the time. In replacing their catastrophist, saltationist model with a uniformitarian, steadily evolving model men of science had dispensed with God as 'master-magician', and opened up the possibility of reconstructing natural theology in a more awe-inspiring and therefore truer fashion. The 'master magician' was demeaned by his worshippers every time they called on him (during official fast days, for example) to act 'on' or 'interrupt' nature as if interacting with something outside Himself. ${ }^{95}$

\section{V}

In his survey of Victorian historiography, A Liberal Descent (1981), John Burrow has described how the historians William Stubbs and Edward Augustus Freeman built on earlier work of J. M. Kemble to create 'a new kind of history', one that replaced eighteenth-century antiquarian narratives of Ancient Constitution and Norman Yoke with a story of continuity, 'by definition uneventful': 'The history, or perhaps the embry-

\footnotetext{
90 Argyll, Primeval Man: An Examination of Some Recent Speculations (1869), p. 192.

91 Daniel Pick, Faces of Degeneration: A European Disorder, c. 1848-c. 1918 (Cambridge, 1989) [hereafter Pick, Degeneration], p. 192.

${ }_{92}$ Stepan, Idea of Race, p. 73; Desmond, Archetypes and Ancestors, p. 109.

93 Pick, Degeneration, pp. 207 (quote), 209.

${ }_{94}$ Kingsley to Huxley, 21 Sept. 1860. HP, Gen. Letters IX, fo. 162.

${ }^{95}$ Frank Turner, 'Rainfall, Plagues and the Prince of Wales', in Turner, Victorian Intellectual Life, p. 155 .
} 


\section{AN ILLIBERAL DESCENT}

1 ology, of the constitution was to be the putative story of a continuous process of cellular multiplication, amalgamation and expansion, whose code was contained in its nuclear primal cell ... the mark-community, vicus or self-regulating township'. ${ }^{96}$ Elsewhere Burrow speaks of Freeman's 'delight in restorations, his pleasure in cycles and recapitulation ...the Whig honours-board becomes a record of almost literal metempsychoses. ${ }^{97}$ As this article has demonstrated, these terms are helpful for thinking about Kingsley, too. In Kingsley's case, however, the oscillation between scientific and historical terms was more than a case of serendipitous homologies or even conscious borrowings on the part of the historian. For Kingsley, indeed, translation or slippage between the two languages was impossible. They were destined to merge into a reinvented science of Natural Theology. Though Burrow's slightly hesitant use of these terms highlights the same processes of reproduction, assimilation and recapitulation as those considered here, in speaking of an embryology of the constitution he is placing the wrong entity at the heart of the Teutonist model of historical development. It should be 'race', not 'constitution'.

'Race' was not just another way of saying 'nation' or 'culture'; if anything, it was the sworn enemy of it. Though difficult to pin down and less concrete than institutions, as in Herbert Spencer's model of social development, it was the 'soft' parts (physiological and biological factors) that 'determine the forms of the hard ones' (political systems, laws and institutions).$^{98}$ The Teutonic race was the embryo or soul of this Teutonic history, and the constitution was secondary, the body it temporarily inhabited until it outgrew it. As Spencer noted, it was this placing of constitutions rather than racial character at the heart of historical narrative that was responsible for 'the small value of historical studies, as they have been commonly pursued, ${ }^{99}$

Assimilationism has been seen as disqualifying the Teutons from being a real race. ${ }^{100}$ But Teutonic assimilations were endogamous, within the 'family of Teutonic races'. There were plenty of races that could not join: 'negros', Turks, but also Celts. Kingsley and Freeman saw races as endowed with characteristics at the beginning, characteristics which were then expressed (the use of that verb in contemporary genetics was unknown to Kingsley, but the slippage is felicitous) over time, in nations. Nor was there any such thing as the 'remote' past, as analogies shattered linear time. Race was the key to the maze of contemporary events. The historian's role was to look beyond the surface of factional politics, legislative acts and battles to perceive the racial patterns which indicated

\footnotetext{
96 John Burrow, A Liberal Descent: Victorian Historians and the English Past (Cambridge, 1981), pp. 124-5.

${ }^{97}$ Ibid., pp. 220-1.

98 Spencer, Social Statics, p. 214.

99 Spencer, 'The Social Organism' [originally Westminster Review, January 1860], in Essays, i. 266.

${ }_{100}$ Peter Mandler, English National Character: The History of an Idea from Edmund Burke to Tony Blair (New Haven, 2006), p. 60.
} 
where each piece fitted. As Kingsley's opposite number at Oxford in the 1860s, Goldwin Smith put it, when trying to establish why a particular empire rose and another fell 'about the only answer that we get to these questions is race. ${ }^{101}$

There certainly were absurd and unpleasant aspects to Kingsley's attempt to unify evolutionary biology and national history. As a 'science of history', it obviously lacks coherence. But to imply that absurdity somehow prevented such racialist Providential histories from gaining an audience, that they represented an eccentric movement on the fringes of the profession and discipline that Freeman, Seeley and Stubbs were struggling to establish, is tantamount to suggesting that incoherent beliefs remain unpopular simply because they are incoherent. As the multiple editions of Kingsley demonstrate, his histories were widely read for at least fifty years after his death. Filmed versions of The Water Babies and Westward Ho! appeared in Britain as early as 1907 and 1919 respectively. Admittedly, after the 1890s his books were almost exclusively read by children and young adults, but that did not mean passing into oblivion. As Michael Banton has noted, 'In a loose and unphilosophical way [Kingsley's] novels must have encouraged English people to think in racial categories and to believe that this was a key to the understanding of history. ${ }^{102}$ Though Kingsley's stature has suffered much from the professionalization of the many disciplines to which he contributed, his Providential yet scientific national history cast a longer shadow than we might care to admit.

\footnotetext{
101 Goldwin Smith, 'The Greatness of the Romans', in Lectures and Essays (New York, 1881), pp. 1-20 (2-3). See also 'The Greatness of England', Contemporary Review, xxxiv (1879), 1-18, at p. 9. ${ }^{102}$ Michael Banton, 'Kingsley's Racial Philosophy', Theology, lxxviii (1975), 22-30, at p. 30. 
JOBNAME: No Job Name PAGE: 22 SESS: 7 OUTPUT: Thu Feb 17 13:49:17 2011 /v2503/blackwell/journals/hist_v96_i2/hist_513

\begin{tabular}{|l|l|}
\hline \multicolumn{2}{|c|}{ Toppan Best-set Premedia Limited } \\
\hline Journal Code: HIST & Proofreader: Elsie \\
\hline Article No: 513 & Delivery date: 17 February 2011 \\
\hline Page Extent: 21 & Copyeditor: Rhona \\
\hline
\end{tabular}

